\title{
PERANCANGAN SISTEM HYBRID PEMBANGKIT LISTRIK TENAGA SURYA DENGAN TURBIN ANGIN TERAPUNG
}

\author{
Muhammad Firman ${ }^{1, a}$, Muhammad Irfansyahº, \\ (1)(2)Teknik Mesin, Fakultas Teknik, Universitas Islam Kalimantan MAB \\ Jl. Adhiyaksa No. 2 Kayu Tangi, Banjarmasin \\ Email :firmanuniska99@gmail.com
}

\begin{abstract}
Abstrak
Penduduk Kalimantan Selatan memanfaatkan sungai sebagai transportasi dan tempat berlangsungnya banyak kegiatan sehari-hari. mulai dari transportasi, jual-beli dan lainlain. Pada malam hari aktivitas masyarakat yang menggunakan transportasi sungai hampir tidak ada, karena sepanjang aliran sungai tidak terdapat penerangan untuk mengarahkan rute jalan yang akan dilalui, sehingga masyarakat enggan untuk melakukan aktivitas pada malam hari di sepanjang aliran sungai. Selama ini kalau mereka melakukan aktivitas juga biasanya pada saat langit cerah atau pada saat bulan terang, karena jarak pandang bisa lebih jauh. Sistem pembangkit yang digunakan untuk di hybrid pada penelitian ini adalah pembangkit listrik tenaga surya dengan turbin angin. Sistem ini merupakan salah satu alternatif sistem pembangkit yang tepat diaplikasikan pada daerah-daerah yang sukar dijangkau oleh sistem pembangkit besar seperti jaringan PLN atau Pembangkit Listrik Tenaga Diesel (PLTD).

Untuk memperjelas permasalahan yang akan diteliti, maka masalah tersebut dirumuskan sebagai berikut : bagaimana merancang sistem hybrid PLTS dengan turbin angin terapung?, berapa kemampuan apungnya jika diberi beban maksimum dan bagaimana kesetimbangannya?, berapa lama baterai membackup beban pada sistem hybrid?, berapa lama waktu pengisian baterai dengan menggunakan turbin angin?, dab berapa lama waktu pengisian baterai dengan menggunakan PLTS?. Adapun luaran dari penelitian ini diharapkan rancangan sistem hybrid PLTS dengan turbin angin terapung ini nantinya bisa menjadi dasar acuan jika mau membuat model yang sebenarnya untuk di gunakan pada daerah sepanjang aliran sungai pada saat malam hari, sebagai pengembangan mata kuliah mekanika Teknik dan perpindahan panas dan juga laporannya dapat diterbitkan pada Jurnal ilmiah nasional.

Dari hasil perhitungan dan Analisa data maka dapat disimpulkan sebagai berikut: gaya apung turbin angin hybrid PLTS adalah 572,904 N, Titik berat terletak pada koordinat ( $350 \mathrm{~mm}, 450 \mathrm{~mm}$ ), lama baterai membackup beban pada sistem hybrid adalah 9,64 jam, lama waktu pengisian baterai dengan menggunakan turbin angin 20,41 jam, dan waktu pengisian baterai dengan menggunakan PLTS 6,02 jam.
\end{abstract}

Kata kunci: sistem hybrid, turbin angin, terapung

\begin{abstract}
The people of South Kalimantan use the river as transportation and a place where many daily activities take place. ranging from transportation, buying and selling and others. At night, community activities using river transportation are almost non-existent, because along the river there is no lighting to direct the route to be traversed, so people are reluctant to carry out activities at night along the river. So far, when they do activities, usually when the sky is clear or when the moon is bright, because the
\end{abstract}


visibility can be farther. The generating system used for hybrid in this study is a solar power plant with a wind turbine. This system is an alternative generator system that is appropriate to be applied to areas that are difficult to reach by large power generation systems such as the PLN network or Diesel Power Plant (PLTD).

To clarify the problem to be studied, the problem is formulated as follows: how to design a PV mini-grid system with a floating wind turbine?, what is the buoyancy ability if it is given a maximum load and how is it balanced?, how long does the battery back up the load on the hybrid system?, how long does it take? charging the battery using a wind turbine?, and how long does it take to charge the battery using PLTS?. As for the output of this research, it is hoped that the design of a PLTS hybrid system with a floating wind turbine can later be used as a basis for reference if you want to make an actual model to be used in areas along the river at night, as a development course in Engineering mechanics and heat transfer and also the report can be published in national scientific journals.

From the results of calculations and data analysis, it can be concluded as follows: the buoyant force of the PLTS hybrid wind turbine is 572,904 N, the center of gravity is located at the coordinates $(350 \mathrm{~mm}, 450 \mathrm{~mm})$, the length of time the battery backs up the load on the hybrid system is 9.64 hours, the length of time charging the battery using a wind turbine is 20.41 hours, and the battery charging time using PLTS is 6.02 hours.

Keywords: hybrid system, wind turbine, floating

\section{PENDAHULUAN}

Penduduk Kalimantan Selatan memanfaatkan sungai sebagai transportasi dan tempat berlangsungnya banyak kegiatan sehari-hari. mulai dari transportasi, jual-beli dan lain-lain. Pada malam hari aktivitas masyarakat yang menggunakan transportasi sungai hampir tidak ada, karena sepanjang aliran sungai tidak terdapat penerangan untuk mengarahkan rute jalan yang akan dilalui, sehingga masyarakat enggan untuk melakukan aktivitas pada malam hari di sepanjang aliran sungai. Untuk Kalimantan Selatan khususnya wilayah Banjarmasin potensi tenaga surya diperkirakan memiliki distribusi penyinaran sekitar $4,5 \mathrm{kWh} / \mathrm{m}^{2} /$ hari. Energi listrik yang dihasilkan sel surya sangat dipengaruhi oleh intensitas cahaya matahari yang diterima oleh sistem. Sistem hybrid Adalah penggunaan 2 sistem atau lebih pembangkit listrik dengan sumber energi yang berbeda. Sistem pembangkit yang digunakan untuk di hybrid pada penelitian ini adalah pembangkit listrik tenaga surya dengan turbin angin. Sistem ini merupakan salah satu alternatif sistem pembangkit yang tepat diaplikasikan pada daerahdaerah yang sukar dijangkau oleh sistem pembangkit besar seperti jaringan PLN atau Pembangkit Listrik Tenaga Diesel (PLTD). Berdasarkan latar belakang tersebut, maka peneliti mengidentifikasi permasalahan yang berkaitan dengan Perancangan Sistem Hybrid Pembangkit Listrik Tenaga Surya (PLTS) Dengan Turbin Angin Terapung. Sedangkan tujuan dari perancangan ini adalah sebagai berikut: untuk mengetahui model perancangan sebuah sistem hybrid PLTS dengan turbin angin terapung, untuk mengetahui seberapa besar kemampuan apungnya jika diberi beban maksimum dan bagaimana kesetimbangannya, untuk mengetahui lamanya baterai membackup beban pada sistem hybrid, untuk mengetahui lama waktu pengisian baterai dengan menggunakan turbin angin, dan untuk mengetahui lama waktu pengisian baterai dengan menggunakan PLTS. 


\section{METODE PENELITIAN}

Penelitian ini dilakukan dengan menggunakan metode atau pendekatan secara teoritis dan analisis. Kajian secara teoritis untuk mendapatkan parameter-parameter utama, dengan berbagai sumber literatur baik berupa buku teks, jurnal maupun yang bersumber dari internet. Penelitian ini dilakukan dengan tiga tahapan yaitu: Tahap Pertama mengunakan metode pengujian eksperimental (experimental research) yaitu melakukan pengamatan dan pengukuran kecepatan angin di permukaan sungai, juga melakukan penggukuran terhadap keluaran PLTS baik tegangan maupun kuat arus yang dihasilkan, sehinnga nantinya dapat diketahui daya yang dihasilkan oleh PLTS. Selanjutnya data yang didapat tersebut dijadikan sebagai dasar untuk perhitungan turbin angin maupun PLTS. Sedangkan studi kepustakaan (bibliography research), yang gunanya untuk menemukan teori-teori mengenai perancangan system hybrid PLTS dengan turbin angin, teori perhitungan kemampuan apung jika diberi beban maksimum dan kesetimbangannya. Target atau indikator keberhasilan pada tahap ini adalah teridentifikasinya permasalahan tentang bagaimana merancang system hybrid PLTS dengan turbin angin. Tahap Kedua dari gambar rancangan tersebut selanjutnya di analisa sehingga nantinya dapat menentukan kemampuan apung jika diberi beban maksimum dan bagaimana kesetimbangannya sehingga tidak tenggelam. Serta menghitung sistem hybrid PLTS dengan turbin angin terapung. Tahap Ketiga berisikan simpulan dari hasil-hasil perhitungan dan analisa data yang telah dilakukan.

\section{HASIL DAN PEMBAHASAN}

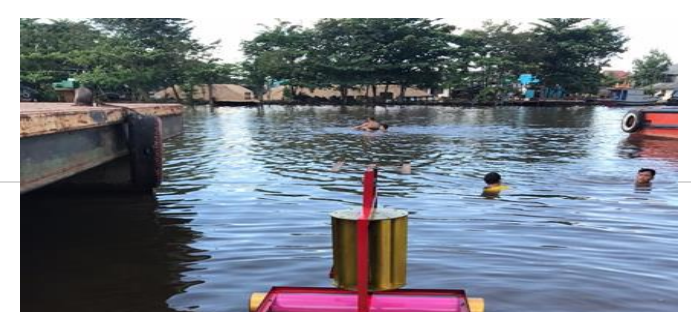

Gambar 1. Rancangan

\section{Menghitung Kemampuan Apung}

Bahan pelampung aluminium dengan Berat jenis $(\mathrm{Bj})=2,7 \mathrm{Kg} / \mathrm{dm}^{3}$

Panjang pelampung $(\mathrm{P})=900 \mathrm{~mm}$

Diameter pelampung $=250 \mathrm{~mm}$

Tebal plat pelampung $(\mathrm{t})=3 \mathrm{~mm}$

Berat pelampung ( $\mathrm{Wp}$ ):

$\mathrm{Wp}=\mathrm{V} \times \mathrm{Bj}$

Dimana :

$\mathrm{V}=$ Volume pelampung $\left(\mathrm{dm}^{3}\right)$

$V=t \cdot \pi \cdot\left\{(P . D p)+\left(3 \cdot \frac{1}{4} \cdot D p^{2}\right)\right\}$

$V=3 \cdot 3,14 \cdot\{(900.250)$

$$
=2,5611 \mathrm{dm}^{3}
$$$$
\left.+\left(3 \cdot \frac{1}{4} \cdot 250^{2}\right)\right\}
$$

$\mathrm{Wp}=$ Berat pelampung $(\mathrm{kgf})$

$\mathrm{Wp}=2,5611.2,7$

$$
=6,915 \mathrm{kgf}
$$

Karena ada dua buah pelampung maka berat nya menjadi:

$\mathrm{Wp}=2 \times 6,915$

$$
=13,83 \mathrm{kgf}
$$

Data yang didapat:

Berat total adalah $30 \mathrm{Kgf}$

Berat pelampung dengan tutupnya $=$ $13,83+1,5=15,33 \mathrm{kgf}$

Diameter pelampung $=250 \mathrm{~mm}=0,25$ $\mathrm{m}$

Panjang pelampung $(\mathrm{Pp})=900 \mathrm{~mm}=$ $0,90 \mathrm{~m}$

- Menentukan volume pelampung (Vp)

$$
\begin{aligned}
\mathrm{Vp} & =\pi \times\left(\mathrm{r}^{2}\right) \times \mathrm{Pp} \\
& =3,14 \times\left(0,125^{2}\right) \times 0,9 \\
& =0,0442 \mathrm{~m}^{3}
\end{aligned}
$$


p-ISSN 2502-4922,e-ISSN 2615-0867

- Menentukan gaya apung pelampung (Fap)

$$
\begin{aligned}
\text { Fap } & =V p \times \rho \times g \\
\text { Fap } & =0,0442 \times 1000 \times 9,81 \\
& =433,602 \mathrm{~N}
\end{aligned}
$$

Karena ada dua pelampung maka kemampuan apungnya adalah:

$$
\begin{aligned}
\text { Fap } & =433,692 \times 2 \\
& =867,204 \mathrm{~N}
\end{aligned}
$$

Sedangkan jika berat total adalah: $30 \mathrm{Kgf}$

Gaya grafitasi $(\mathrm{Fg})=$ Berat total $\mathrm{x} \mathrm{g}$

$\mathrm{Fg}=30 \mathrm{kgf} \times 9,81 \mathrm{~N} / \mathrm{kgf}$

$$
=294,3 \mathrm{~N}
$$

Maka bagian yang tidak tenggelam adalah sebesar:

$$
\begin{aligned}
\text { Fapk } & =867,204 \mathrm{~N}-294,3 \mathrm{~N} \\
& =572,904 \mathrm{~N}
\end{aligned}
$$

\section{Menentukan Koordinat Titik Berat}

Data yang diketahui adalah:

Panjang total perahu $=900 \mathrm{~mm}$

Lebar total perahu $\quad=700 \mathrm{~mm}$

Berat total perahu $=30 \mathrm{kgf}$

Titik berat penampang perahu terletak pada:

$$
\begin{aligned}
X_{o}=\frac{(\epsilon G \cdot x)}{\epsilon G} & =\frac{(30 \mathrm{kgf} \cdot 350 \mathrm{~mm})}{30 \mathrm{kgf}} \\
Y_{O}=\frac{(\epsilon G \cdot y)}{\epsilon G} & =\frac{(350 \mathrm{~mm}}{30 \mathrm{kgf} \cdot 450 \mathrm{~mm})} \\
& =450 \mathrm{~mm}
\end{aligned}
$$

\begin{tabular}{|c|c|c|c|c|}
\hline No & $\begin{array}{c}\text { Kecepatan } \\
\text { angin } \\
(\mathrm{m} / \mathrm{s})\end{array}$ & $\begin{array}{l}\text { Putaran } \\
\text { poros } \\
\text { (rpm) }\end{array}$ & $\begin{array}{l}\text { Tegangan } \\
\text { (v) }\end{array}$ & $\begin{array}{l}\text { Arus } \\
\text { (A) }\end{array}$ \\
\hline \multirow{4}{*}{1} & \multirow{3}{*}{3,2} & 89,9 & 17,1 & 0,30 \\
\hline & & 67,7 & 15,4 & 0,26 \\
\hline & & 88,8 & 16,8 & 0,33 \\
\hline & Rata-rata & 82,13 & 16,43 & $\mathbf{0 , 3 0}$ \\
\hline \multirow{4}{*}{2} & \multirow{3}{*}{3,7} & 205 & 23,7 & 0,41 \\
\hline & & 208,4 & 24,9 & 0,43 \\
\hline & & 209,9 & 26,9 & 0,45 \\
\hline & Rata-rata & 207,77 & 25,17 & $\mathbf{0 , 4 3}$ \\
\hline \multirow{4}{*}{3} & \multirow{3}{*}{4,2} & 239,5 & 29,5 & 0,47 \\
\hline & & 232,8 & 28,3 & 0,43 \\
\hline & & 240,5 & 37,4 & 0,56 \\
\hline & Rata-rata & 237,6 & 31,73 & 0,49 \\
\hline
\end{tabular}

Jadi koordinat titik beratnya berada $\mathrm{Z}($ $\mathrm{Xo}, \mathrm{Yo})=\mathrm{Z}(350 \mathrm{~mm}, 450 \mathrm{~mm})$

\section{Daya Keluaran Dari Turbin Angin}

Pada tahapan ini adalah menghitung daya yang dihasilkan turbin angin yang nantinya digunakan sebagai penyuplai daya pada baterai saat malam hari.

Data yang didapat dari hasil pengujian adalah sebagai berikut:

Tabel 1 Data hasil pengujian

Dari data pengujian yang di dapat maka kita bisa mendapatkan daya rata-rata yang dihasilkan turbin.

$$
\begin{aligned}
\mathrm{P} & =\mathrm{V} \times \mathrm{I} \\
\mathrm{P} & =16,43 \times 0,30 \\
& =4,93 \text { Watt }
\end{aligned}
$$

Dengan cara yang sama maka didapatkan data seperti pada table 4.2 dibawah ini.

Tabel 2 Daya rata-rata yang dihasilkan turbin

\begin{tabular}{|c|c|c|c|c|c|}
\hline No & $\begin{array}{c}\text { Kecepatan } \\
\text { angin } \\
(\mathrm{m} / \mathrm{s})\end{array}$ & $\begin{array}{c}\text { Putaran } \\
\text { poros } \\
(\mathrm{rpm})\end{array}$ & $\begin{array}{c}\text { Tegangan } \\
(\mathrm{v})\end{array}$ & $\begin{array}{c}\text { Arus } \\
(\mathrm{A})\end{array}$ & $\begin{array}{c}\text { Daya } \\
\mathrm{P} \\
(\text { Watt })\end{array}$ \\
\hline 1 & 3,2 & 82,13 & 16,43 & 0,30 & 4,93 \\
\hline 2 & 3,7 & 207,77 & 25,17 & 0,43 & 10,82 \\
\hline 3 & 4,2 & 237,6 & 31,73 & 0,49 & 15,55 \\
\hline & Rata-rata & 175,83 & 24,44 & 0,41 & 10,43 \\
\hline
\end{tabular}

Jadi jika kecepatan angin antara 3,2 sampai 4,2 maka daya yang dihasilkan oleh turbin angin adalah 10,43 Watt.

Daya terpasang pada system hybrid adalah sebagai berikut:

Baterai yang digunakan 12 Volt, 10 Amper

\begin{tabular}{|l|l|l|l|c|c|c|c|}
\hline No & $\begin{array}{c}\text { Nama } \\
\text { Barang }\end{array}$ & Produk & Unit & $\begin{array}{c}\text { Daya } \\
\text { (Watt } \\
\text { ) }\end{array}$ & $\begin{array}{c}\text { Tega } \\
\text { ngan } \\
\text { (Volt) }\end{array}$ & $\begin{array}{c}\text { Jam/ } \\
\text { Hari }\end{array}$ & $\begin{array}{c}\text { TOTAL } \\
\text { DAYA } \\
\text { Wattjam } \\
\text { ( Wh })\end{array}$ \\
\hline 1 & $\begin{array}{l}\text { Lampu } \\
\text { LED }\end{array}$ & Philip & $\begin{array}{l}2 \times \\
\text { @ 5 } \\
\text { W }\end{array}$ & 10 & 12 & 12 & 120 \\
\hline \multicolumn{6}{|c|}{ Jumlah Daya Per hari } \\
\hline
\end{tabular}

Daya listrik perhari sebesar $120 \mathrm{Wh}$ ditambahkan sekitar 20 persen untuk 
digunakan oleh perangkat lain, yaitu inverter dan controller.

Jika ditambahkan 20\%, maka total daya listrik perhari adalah:

Total Daya listrik perhari $=120+(120$ x $20 \%)=144 \mathrm{Wh}$.

a. Perhitungan Beban Sistem Yang Disuplai

Ada dua sistem penyuplai energi listrik yaitu dari modul surya dan turbin angin.

Pada sistem hybrid yang di rencanakan penggunaan PLTS sebesar 41,67\% dan turbin angin 58,33\%.

Besar energi yang disuplai oleh Turbin angin adalah:

$\mathrm{E}_{\mathrm{TA}}=58,33 \% \times$ Total daya listrik perhari

$\mathrm{E}_{\mathrm{TA}}=58,33 \% \times 144 \mathrm{Wh}$ $=83,9952 \mathrm{Wh}=84 \mathrm{Wh}$

\section{b. Perhitungan Kapasitas Baterai (Amper Jam)}

Kuat Arus $(\mathrm{I})=84 \mathrm{Wh} / 12 \mathrm{~V}=7$ Amperjam ( Ah ).

Digunakan baterai yang mempunyai kapasitas sebesar $10 \mathrm{Ah} 12 \mathrm{~V}$, maka membutuhkan baterai sebanyak $=7 \mathrm{Ah}$ / $10 \mathrm{Ah}=0,7$ baterai atau 1 baterai.

Maka jumlah daya yang dihasilkan baterai $=10 \mathrm{Ah} \times 12 \mathrm{~V} \times 1=120 \mathrm{Wh}$.

\section{c. Perhitungan Kapasitas Daya Turbin Angin}

Dengan mengetahui jumlah daya yang dihasilkan baterai sebesar $120 \mathrm{Wh}$, pada perancangan ini turbin angin mempunyai kapasitas 10,43 Watt, jika dalam satu hari mendapat hembusan angin selama 14 jam, maka turbin angin ini mampu mensuplai daya listrik sejumlah:

Daya listrik yang mampu di suplai = 10,43 Watt x 14 Jam

146,02 Wattjam ( Wh )

\section{d. Perhitungan Lama Baterai Membackup Beban Pada Sistem Hybrid}

Data yang ada: Beban terpasang

$$
=10 \mathrm{Watt}
$$

Baterai yang

digunakan $=12 \mathrm{~V} 10 \mathrm{Ah}$

$\mathrm{I}=\mathrm{P} / \mathrm{V}$

Dimana: $\mathrm{I}=$ Kuat arus (Amper )

$$
\begin{aligned}
& \mathrm{P}=\text { daya }(\text { Watt }) \\
& \mathrm{V}=\text { Tegangan }(\text { Volt })
\end{aligned}
$$

Jadi: I = 10 Watt $/ 12 \mathrm{~V}$

$$
=0,83 \text { Amper }
$$

Maka lamanya baterai

membackup beban adalah:

$10 \mathrm{Ah} / 0,83 \mathrm{~A}=12,05 \mathrm{jam}-$ $2,41 \mathrm{jam}=9,64 \mathrm{jam}$

\section{e. Perhitungan Lama Waktu}

\section{Pengisian Baterai Oleh Turbin} Angin

Data percobaan didapat:

Voltase Baterai 12 volt

Kapasitas Baterai $10 \mathrm{Ah}$

Kuat arus hasil percobaan 0,41

Amp $+20 \%=0,49$ untuk

diefisiensi baterai

Jadi lama Pengisian :

$10 \mathrm{Ah} /$ 0,49 Amp = 20,41 jam

\section{Daya Yang Dihasilkan Oleh Solar Cell}

Daya listrik perhari sebesar 100 Wh ditambahkan sekitar 20 persen untuk digunakan oleh perangkat lain, yaitu inverter dan controller. Jika ditambahkan 20\%, maka total daya listrik perhari adalah: $100+(100 \mathrm{x}$ $20 \%)=120 \mathrm{Wh}$.

\section{a. Perhitungan Beban Sistem Yang Disuplai Solar Cell}

Pada perancangan ini penggunaan PLTS sebesar $41,67 \%$ sehingga besar energi yang disuplai oleh PLTS adalah:

EPLTS $=41,67 \% \times$ Total daya listrik perhari

$$
\begin{aligned}
\mathrm{E}_{\text {PLTS }} & =41,67 \% \times 120 \mathrm{Wh} \\
& =50 \mathrm{Wh}
\end{aligned}
$$

\section{b. Perhitungan Kapasitas Daya Solar Cell}


p-ISSN 2502-4922,e-ISSN 2615-0867

Pada perancangan ini modul surya yang digunakan mempunyai kapasitas 20 Watt Peak (WP), jika dalam satu hari mendapat penyinaran matahari selama 10 jam maka modul surya ini mampu mensuplai daya listrik sejumlah:

Daya listrik yang mampu di suplai $=20$ Watt $\times 10$ Jam

$$
=200 \text { Wattjam }(\mathrm{Wh})
$$

Total modul surya $=120 \mathrm{Wh} / 200$

$\mathrm{Wh}=0,6$ atau 1 modul.

Tabel 3 Data hasil penelitian solar cell

\begin{tabular}{|c|c|c|}
\hline Jam & $\begin{array}{c}\text { Tegangan } \\
\text { (volt) }\end{array}$ & $\begin{array}{c}\text { Arus } \\
\text { (ampere) }\end{array}$ \\
\hline $07.00-08.00$ & 3.4 & 0.53 \\
\hline $08.00-09.00$ & 4.7 & 1.45 \\
\hline $09.00-10.00$ & 4.4 & 1.37 \\
\hline $10.00-11.00$ & 5.2 & 1.53 \\
\hline $11.00-12,00$ & 6.7 & 1.72 \\
\hline $12,00-13.00$ & 7.6 & 1.95 \\
\hline $13.00-14.00$ & 6.8 & 1.78 \\
\hline $14.00-15.00$ & 6.3 & 1.63 \\
\hline $15.00-16.00$ & 4.5 & 1.42 \\
\hline $16.00-17.00$ & 2.4 & 0.47 \\
\hline
\end{tabular}

\section{c. Menghitung Besarnya Daya Keluaran Solar Cell}

Besarnya daya dapat di hitung dengan menggunakan pesamaan

$$
\mathrm{P}=\mathrm{V} \text {. I }
$$

Dimana

$\mathrm{P}$ : daya, dalam satuan watt

$\mathrm{V}$ : tegangan dalam satuan volt

I : arus dalam satuan amper

Jadi : $\mathrm{V}=3,4$ Volt

$$
\begin{aligned}
\mathrm{I} & =0,53 \text { Amper } \\
\mathrm{P} & =3,4 \times 0,53 \\
& =1,802 \text { Watt }
\end{aligned}
$$

Dengan perhitungan yang sama maka didapatkan data seperti pada table dibawah ini.

Tabel 4 Data hasil perhitungan daya keluaran solar cell

\begin{tabular}{|c|c|c|c|}
\hline Jam & $\begin{array}{c}\text { Tegangan } \\
\text { (volt) }\end{array}$ & $\begin{array}{c}\text { Arus } \\
\text { (ampere) }\end{array}$ & $\begin{array}{c}\text { Daya } \\
\text { (Watt) }\end{array}$ \\
\hline $07.00-08.00$ & 3.4 & 0.53 & 1.802 \\
\hline $08.00-09.00$ & 4.7 & 1.45 & 6.815 \\
\hline $09.00-10.00$ & 4.4 & 1.37 & 6.028 \\
\hline $10.00-11.00$ & 5.2 & 1.53 & 10,6 \\
\hline $11.00-12,00$ & 6.7 & 1.72 & 11.524 \\
\hline $12,00-13.00$ & 7.6 & 1.95 & 14.82 \\
\hline $13.00-14.00$ & 6.8 & 1.78 & 12.104 \\
\hline $14.00-15.00$ & 6.3 & 1.63 & 10.269 \\
\hline $15.00-16.00$ & 4.5 & 1.42 & 6.39 \\
\hline $16.00-17.00$ & 2.4 & 0.47 & 1.128 \\
\hline Rata-rata & $\mathbf{5 . 2}$ & $\mathbf{1 . 3 8 5}$ & $\mathbf{7 . 0 8 8}$ \\
\hline
\end{tabular}

\section{d. Perhitungan Lama Waktu Pengisian Baterai Oleh Solar Cell}

Data percobaan didapat:

Voltase Baterai 12 volt

Kapasitas Baterai $10 \mathrm{Ah}$

Kuat arus hasil percobaan 1,385

Amp $+20 \%=1,662$ untuk

diefisiensi baterai

Jadi lama Pengisian :

$10 \mathrm{Ah} /$ 1,662 Amp = 6,02 jam

\section{Perhitungan Kapasitas Battery Charger Regulator (BCR)}

Dari spesifikasi modul surya yang telah di ketahui yang harus diperhatikan adalah angka Isc (short circuit current) $=8,53 \mathrm{~A}$, kita kalikan dengan jumlah modul surya, sehingga hasilnya merupakan nilai minimal dari charger regulator yang dibutuhkan. 1 modul surya $20 \mathrm{Wp}$ yang digunakan akan butuh charger regulator yang mempunyai kuat arus:

$8,53 \mathrm{~A} \times 1=8,53$ A. Maka sebaiknya kita gunakan charger regulator yang $10 \mathrm{~A}, 12 \mathrm{~V}$ agar lebih aman. Sedangkan inverter yang digunakan pada sistem ini adalah inverter yang mampu menghasilkan efisiensi tinggi (sekitar 85\% - 90\% ke atas) dari besar daya yang maksimum.

\section{KESIMPULAN}


Dari hasil perhitungan dan Analisa data maka dapat disimpulkan:

1. Gaya apung turbin angin hybrid PLTS adalah 572,904 N

2. Titik berat terletak pada koordinat ( $350 \mathrm{~mm}, 450 \mathrm{~mm}$ )

3. Lama baterai membackup beban pada sistem hybrid adalah 9,64 jam.

4. Lama waktu pengisian baterai dengan menggunakan turbin angin 20,41 jam.

5. Lama waktu pengisian baterai dengan menggunakan PLTS 6,02 jam

\section{REFERENSI}

[1] I.B. Alit, Nurchayati, P. (2016). Turbin angin poros vertikal tipe Savonius bertingkat dengan variasi posisi sudut. Dinamika Teknik Mesin, 6(2), 107-112.

[2] Muhammad Firman, Budi Hartadi, Idzani Muttaqin, Muhammad Saukani, N. H. (2016). Penyuluhan pengenalan pembangkit listrik tenaga surya (plts) di desa jejangkit muara kabupaten batola. Al-Ikhlas, 2(2), 1-4.

[3] Muhammad Firman, M. I. (2016).

Perencanaan Sistem Hybrid Pembangkit Listrik Tenaga Surya Dengan Genset Pada Laboratorium Lapangan UNISKA Bentok BatiBati. Prosiding Hasil Penelitian, 364-370.

[4] Muhammad Firman, M. I. (2019). Perancangan Perahu Pembersih Sampah Di Aliran Sungai Kota Banjarmasin. AL-Jazari, 4(1), 2228. 